\title{
Phylogenetical coherence of Pseudomonas in unexplored soils of Himalayan region
}

\author{
Stuti Sah $^{1} \cdot$ Rajni Singh ${ }^{1}$
}

Received: 9 June 2016/ Accepted: 7 August 2016/Published online: 13 August 2016

(C) The Author(s) 2016. This article is published with open access at Springerlink.com

\begin{abstract}
Pseudomonas, an enormously diverse genus of the $\gamma$-Proteobacteria, is an important member of soil microbial communities. In this study, genetic heterogeneity and plant growth promotory property of Pseudomonas was compared within the group Pseudomonas sensu stricto isolated from the lesser explored niches of Himalayan region. A significant difference $(P<0.001$ in total Pseudomonas count) was observed among the six types of soil samples collected from oak forest, fine forest, and agricultural soil. The highest numbers of bacteria were isolated from oak forest soil followed by pine forest soil and agricultural soil. $23.52 \%$ of the total 238 isolates were siderophore producers and were identified as Pseudomonas on the basis of PCR amplification using 16S rDNA Pseudomonas specific primer. The molecular analysis by Jaccard's similarity coefficient resulted into eight different clusters and six outlying branches. Some of the clusters include Pseudomonas from forest as well as agricultural land. Among the 51 isolates $100 \%$ were siderophore and IAA producers, $68.62 \%$ were phosphate solubilizers and $62.74 \% \mathrm{HCN}$ producers. The results reveal that isolates from lesser explored area possess beneficial properties and show genetic heterogeneity among them.
\end{abstract}

Keywords Pseudomonas - Plant growth promoters . Siderophore $\cdot$ Genetic diversity

Rajni Singh

rsingh3@amity.edu; rajni_vishal@yahoo.com

1 Amity Institute of Microbial Biotechnology, Amity University, J-3 Block, Sector 125, Noida, UP 201301, India

\section{Introduction}

The genus Pseudomonas encompasses arguably one of the most complex, diverse, and ecologically significant group of bacteria on the planet. Members of the genus are found in large numbers in all the major natural environments (terrestrial, freshwater, and marine) and also form intimate associations with plants and animals. This universal distribution of Pseudomonas suggests a remarkable degree of physiological and genetic adaptability (Spiers et al. 2000). Thus, it is essential to understand the bacterial community structure and diversity in relation to environmental factors and ecosystem functions (Torsvik et al. 1996).

The term Pseudomonad is derived from the Greek word Pseudo (=false) and monad (=a single unit) and literally means "false unit". The earliest classification of Pseudomonads was based on cultural characteristics, such as rod shape, Gram negative reaction, and motility by means of polar flagella. The members of previously described Pseudomonas are now classified into ten genera. These are Pseudomonas, Xanthomonas, Stenotrophomonas, Burkholderia, Gluconobacter, Ralstonia, Comamonas, Brevundimonas, Sphingomonas, and Caulobacter. Migula (1894) described the genus Pseudomonas on the basis of morphological characteristics, and later, Stanier et al. (1966) established the taxonomical (physiological and biochemical properties) basis for the identification of species. Winslow et al. (1917) placed Pseudomonads in the family Pseudomonadaceae. Since then, its taxonomy has undergone many changes.

Based on the DNA-DNA hybridization (DDH) and rRNA-DNA hybridization results (Palleroni 1984), the genus was revised, and a subdivision of five groups was implemented. RNA homology group I includes species, such as Pseudomonas aeruginosa, $P$. fluorescens, $P$. 
syringae, $P$. putida, $P$. chlororaphis, $P$. stutzeri, $P$. alcaligens, $P$. pseudoalcaligens, and $P$. mendocina, and are referred to as genus Pseudomonas (sensu stricto) subclass Gamma Proteobacteria (Palleroni 2008). The rRNA similarity group II, the genus Burkholderia, is mainly composed of pathogens except $P$. pickettii. The rRNA similarity group III represents a new genus Comamonas and includes five species. The rRNA group IV represents Gluconobacter species, and group V represents Xanthomomonas. With the initiation of DNA fingerprinting techniques like ARDRA and RFLP as well as 16S rDNA sequencing, several monophyletic groups have been defined and number of species earlier placed in the genus Pseudomonas have moved to different genera, but Pseudomonas sensu stricto remains robust and as diverse as originally reported by Stanier et al. (1966). The number of species in the genus has increased every year (10 additional species in 2013 and six in 2014 through October) (Gomila et al. 2015). At present, the number of validly published species includes 144 species (including 10 subspecies); these species are present in the List of Prokaryotic Names with Standing in Nomenclature (Parte 2014).

The 16S rDNA gene from Pseudomonas spp. contains 1492 nucleotide position, of which 148 are variable and 65 positions of these are within three hypervariable regions. Primers based on these regions have been used to study the diversity of Pseudomonad isolates from different parts of the world (Moore et al. 1996). Remarkable degree of variability has been reported among strains of species that are phylogenetically closely related based on restriction fragment length polymorphism (Ginard et al. 1997; Rainey et al. 1994).

Bacterial diversity is found to decline with the increasing disturbance frequencies. Total bacterial abundance is, however, higher at intermediate and high disturbance frequencies, compared to low and no-disturbance treatments. Increased disturbance frequency also led to changes in community composition, with changes in overall species composition. With increasing disturbance frequency, phylogenetic species variability (an index of community composition) itself became more variable from one sample to another, suggesting a greater role of chance in community composition.

Pseudomonads being one of the most diverse bacterial genera throughout the planet play a key role in soil. Their distribution in soil plays a key role in plant growth promotion and pathogenicity control. Therefore, it is worthwhile to study the Pseudomonas diversity in lesser explored area of natural niches.

In this study, we isolated fluorescent Pseudomonas from a lesser explored area of Indian Central Himalayan region, examined their comparative genetic diversity and analyzed their ability to colonize rhizosphere of majority of plants and their plant growth promoting efficiency.

\section{Material and method}

\section{Isolation and enumeration of bacteria}

Soil samples at a depth of 1-10 cm (surface soil) and 2$3 \mathrm{ft}$ (deep soil) were collected from three sites (Pinus forest, Quercus forest, and agricultural land) and air dried. One gram of each soil sample was added to $10 \mathrm{ml}$ of $0.1 \%$ (w/v) distilled water. After homogenization, this solution was serially diluted $\left(10^{-1}\right.$ to $\left.10^{-8}\right)$ and aliquots were plated in triplicates on (a) King's B (g/l) proteose peptone-20, $\mathrm{K}_{2} \mathrm{HPO}_{4}-1, \mathrm{MgSO}_{4} \cdot 7 \mathrm{H}_{2} \mathrm{O}-0.4$, glycerol-8 $\mathrm{ml}$, agar20, pH 7 (King et al. 1954). (b) Gould's media (g/l) sucrose 10.0, glycerol 10.0, casamino acid 5.0, $\mathrm{NaHCO}_{3} 1.0$, $\mathrm{MgSO}_{4} \cdot 7 \mathrm{H}_{2} \mathrm{O} 1.0, \mathrm{~K}_{2} \mathrm{HPO}_{4} 2.3$, sodium lauryl sulfate(SLS) 1.2 , trimethoprim $20 \mathrm{mg}$ (filter sterilization) add after medium is autoclaved and cooled, $\mathrm{pH}$ 7.4-7.6 (Gould et al. 1985). (c) Nutrient agar. (d) Tryptic soya agar. Plates were incubated at $28^{\circ} \mathrm{C}$, for $24 \mathrm{~h}$. The number of colonies for each dilution plated on both media was enumerated and colony forming units (CFUs) were expressed as:

Colony forming units $=\frac{\text { Number of colonies }}{\text { Dilution factor }} \times$ Volume.

\section{Screening for siderophore producing isolates}

Two hundred and thirty-eight colonies isolated from pine forest, oak forest, and agricultural land soil were inoculated in King's B broth for mother culture preparation and incubated at $28{ }^{\circ} \mathrm{C}$ and $120 \mathrm{rpm}$ for $24 \mathrm{~h}$. Loop full of overnight grown culture was spot inoculated on chrome azurol ' $\mathrm{S}$ ' agar media (CAS media) for screening of siderophore producing isolates containing: (A) chrome azurol ' $\mathrm{S}$ ', (B) $1 \mathrm{mM} \mathrm{FeCl}_{3} \cdot 6 \mathrm{H}_{2} \mathrm{O}$ in $\mathrm{HCl}$, and (C) HTMA in nutrient agar (pH 7) (Schwyn and Neilands 1987). These plates were kept in incubator at $28{ }^{\circ} \mathrm{C}$ for $48 \mathrm{~h}$. A total of 51 isolates were found positive on CAS media plate for siderophore production.

\section{Extraction of DNA}

Genomic DNA of all the 56 siderophore producing strains was extracted by a modified method of Bazzicalupo and Fani (1995). Extracted genomic DNA was electrophoresed in $0.8 \%$ agarose gel (with ethidium bromide at a final concentration of $0.5 \mu \mathrm{g} / \mathrm{ml}$ ) at 80 volts. Gel was then visualized under ultraviolet light using a gel documentation system, Gel Doc Mega (Biosystematica). 
Identification of presumptive Pseudomonas isolates by amplification of $16 \mathrm{~S}$ rDNA using Pseudomonas specific primers

Pseudomonas specific primers forward primer Ps-for $\left(5^{\prime}\right.$ GGTCTGAGAGGATGATCAGT $3^{\prime}$ ) and the reverse primer, Ps-rev ( $5^{\prime}$ TTAGCTCCACCTCGCGGC $3^{\prime}$ ) were used to amplify a 990-bp region of $16 \mathrm{~S}$ rRNA gene (Widmer et al. 1998). Genomic DNA of 51 presumptive Pseudomonas isolates was used on thermal cycler, Gen Amp PCR System 9700 (Applied Biosystems). A $50 \mu \mathrm{l}$ of reaction mixture included, $5 \mu \mathrm{l}$ (5-10 ng) of bacterial DNA as template, $5 \mu \mathrm{l}$ of 10X buffer for Taq DNA Polymerase (100 mM of TRIS$\mathrm{HCl}$ and $15 \mathrm{mM} \mathrm{MgCl}_{2}$ ), $2.5 \mu \mathrm{M}$ of each primer, $250 \mu \mathrm{M}$ of dNTPs, and one unit of Taq DNA polymerase (Bangalore Genei, India). The reaction condition includes an initial denaturation of $5 \mathrm{~min}$ at $95^{\circ} \mathrm{C}$, followed by 35 cycles of $1 \mathrm{~min}$ at $94{ }^{\circ} \mathrm{C}, 1 \mathrm{~min}$ at $57^{\circ} \mathrm{C}$ and $1 \mathrm{~min}$ at $72{ }^{\circ} \mathrm{C}$ with the final extension of $10 \mathrm{~min}$ at $720^{\circ} \mathrm{C}$. Amplified DNA was visualized after electrophoresis using UV gel documentation system GelDocMega (Biosystematica).

\section{Restriction fragment length polymorphism analysis}

Aliquots of purified 16S rRNA Pseudomonas specific gene region (990 bp) amplicon were further digested separately with three restriction endonucleases $A l u \mathrm{I}, M s p \mathrm{I}$, and $R s a \mathrm{I}$ restriction enzymes. The reaction mixture included $20-\mu 1$ aliquot of the amplicon as template, $1 \mathrm{X}$ enzyme buffer and $1 \mathrm{U} / \mathrm{rxn}$ of each restriction enzyme, and was digested at $37{ }^{\circ} \mathrm{C}$ for $2 \mathrm{~h}$. Digested products were analyzed by agarose gel $(2.5 \%)$ electrophoresis. Data for the presence or absence of bands were scored in binary format (0-1). Jaccard similarity coefficient was used by DendroUPGMA method for construction of dendrograms.

\section{Physicochemical properties}

\section{Hydrogen cyanide (HCN) production}

Production of $\mathrm{HCN}$ for selected isolates was assessed on King's B medium (KB) containing $4.4 \mathrm{~g} / \mathrm{l}$ of glycine with indicator paper (Whatman soaked in $0.5 \%$ (w/v) picric acid and $2 \%$ (w/v) sodium carbonate), and plates were incubated at $27{ }^{\circ} \mathrm{C}$ for $48 \mathrm{~h}$ to $72 \mathrm{~h}$. Change in color of the indicator paper from yellow to cream, light brown, dark brown, and brick red indicates $\mathrm{HCN}$ production (Alström and Burns 1989).

\section{Phosphate solubilization}

Pikovskaya's agar medium was used to check the phosphate solubilization property (Pikovskaya 1948). Mother culture was prepared in King's B broth and spot inoculated on the Pikovskaya's agar plates. The plates were kept for incubation at $28{ }^{\circ} \mathrm{C}$ for $24 \mathrm{~h}$. A clear zone indicates the phosphate solubilising property of isolates.

\section{Production of indoleacetic acid}

Indoleacetic acid (IAA) production was detected as described by Brick et al. (1991). Bacterial cultures were grown for $48 \mathrm{~h}$ (Pseudomonas) on their King's B media at $36 \pm 2{ }^{\circ} \mathrm{C}$. Fully grown cultures were centrifuged at $3000 \mathrm{rpm}$ for $30 \mathrm{~min}$. The supernatant $(2 \mathrm{ml})$ was mixed with two drops of orthophosphoric acid and $4 \mathrm{ml}$ of the Salkowski reagent $(50 \mathrm{ml}, 35 \%$ of perchloric acid, $1 \mathrm{ml}$ $0.5 \mathrm{M} \mathrm{FeCl}_{3}$ solution). The development of pink color indicates IAA production.

\section{Results}

\section{Isolation and enumeration of bacteria}

A total of 238 bacterial strains were isolated from different soils, and the highest numbers of bacteria were reported from the oak forest soils (surface and deep) followed by pine forest soil and agricultural land soil. The results of this study revealed that the maximum amount of total bacterial population, i.e., $44 \%$ was isolated from oak forest soil. It was further analyzed that oak surface soil (OSS) contributed $24.78 \%$, followed by oak deep soil (ODS) that represented $20.16 \%$ of total oak bacterial count.

On analyzing the contribution of pine forest in total bacterial count, it was found that only $29 \%$ of total bacterial count was from pine forest soil. The data further exhibited that out of $29 \%$, the pine forest soil (PSS) contributed $16.80 \%$, followed by pine deep soil (PDS) $13.86 \%$. The least percentage of total bacterial count (23\%) was reported from agricultural soil ecosystems. The data showed that agricultural surface soil (ASS) contributed $15.54 \%$ of bacterial count, whereas agricultural deep soil (ADS) contributed only $8.82 \%$ of bacterial count.

Reports have shown that the size and structure of microbial populations are affected by soil type and plant species (Sah et al. 2016). Total bacterial count was analyzed for all six soil types and compared for significant differences among them through one way analysis of variance (ANOVA). It was found that the soil bacterial count differed significantly across all six soil types $(F=104.690, d f=5 ; P<0.001)$. We also explored the data further via Tukey's post hoc multiple comparisons for soil bacterial count between various soil groups (i.e., a pair by pair analysis). Tukey's post hoc multiple comparisons 
revealed that there is a statistically significant difference $(P<0.05)$ in bacterial count when PSS is compared with other soil types, i.e., PDS, OSS, ODS, and ADS (Table 1).

There was a significant difference when PDS was compared with PSS, OSS, ODS, and ADS with a mean difference of $-7.0,-15.0,-26.0,-15.0$, and 12.0 , respectively, while no significant difference was observed in PDS and ASS and a mean difference of -4.0 was ODS followed by OSS. The highest mean difference of 38.0 was observed between ODS and ADS bacteria count followed by PDS (26.0), ASS (22.0), PSS (19.0), and OSS (-11.0). A mean difference of -3.0 and 4.0 between ASS and PSS/ PDS, respectively, and a value of $P>0.05$ represents that there is no significant difference in their bacterial count. No significant difference is observed between PSS and ASS $(P>0.05$, mean difference 3.00$)$, and PDS and ASS $(P>0.05$, mean difference $=-4.00)$.

\section{Screening for siderophore producing isolates}

All the 238 isolates were investigated for siderophore production. Fifty-six isolates representing a $23.52 \%$ of total bacterial population isolated were positive for siderophore production. Of the 56 siderophore producing isolates, $46.42 \%$ of the isolates belong to the oak forest soil (OSS: $32.14 \%$; ODS: $14.28 \%$ ), $14.99 \%$ from pine forest soil (PSS: $17.85 \%$; PDS: $7.14 \%$ ), and $28.56 \%$ from Agriculture soil (ASS: $23.21 \%$; ADS: $5.35 \%$ ).

We also quantified the siderophore producing Pseudomonas and analyzed it statistically for all six soil types and compared for significant differences among them through one way analysis of variance (ANOVA). It was observed that the siderophore producing Pseudomonas differed significantly across all 6 soil types $(F=18.900$, $d f=5 ; P<0.001)$. We explored the data further via Tukey's post hoc multiple comparisons for siderophore producing Pseudomonas between various soil groups (i.e. a pair by pair analysis).

Tukey's post hoc multiple comparisons for siderophore producing Pseudomonas reveals significant differences in different types of soil from Uttarakhand State of Indian Himalayan Region (IHR) (Table 2). A statistically significant difference was observed in number of siderophore producing Pseudomonas when PSS soil was compared to other soil types, e.g., PDS, OSS, and ADS $(P<0.05)$. A significant difference was also observed in bacterial count of PSS and oak surface soil, while no significant difference was observed between PSS and OSS $(P>0.05)$. When the total number of siderophore producing Pseudomonas in PDS was compared with various soil types, e.g., PSS, ODS, and ASS with a mean difference of $-7.00,-15.00,-7.00$, respectively, it exhibited a statistically significant difference $(P<0.05)$. No statistically significant difference was observed in siderophore producing Pseudomonas between PDS and ADS $(P>0.05)$, whereas a significant difference was observed in siderophore producing Pseudomonas count when OSS was compared with various soil types, e.g., PSS, PDS, ODS, ASS, and ADS with a mean difference of $8.00,15.00,11.00,8.00$, and 15.00 , respectively.

\section{Identification of presumptive Pseudomonas isolates using Pseudomonas specific primer}

Of the 56 isolates, PCR amplification of 16S rDNA Pseudomonas specific region yielded a single amplicon of 990 bp for 51 isolates. Hence, these 51 isolates belong to Pseudomonas (sensu stricto) group. The five isolates which were not amplified may not be from within the Pseudomonas (sensu stricto) group.

Genetic variation among the isolates was analyzed by RFLP of PCR product with three restriction endonucleases (AluI, MspI, and RsaI). Different profiles having four to seven fragments with variation in size were observed after digestion and dendrogram was constructed by Dendro UPGMA method (Fig. 1). The unique digestion patterns observed segregated the isolates into different groups and subgroups. The representatives from various groups were sequenced for conformation.

The dendrogram represented eight different clusters and six outlying branches based on Jaccard's similarity coefficient. Isolates showing less than $75 \%$ similarity were considered as outlying branches. The isolates representing $>75$ to $99 \%$ similarity were considered as one cluster, and isolates representing $<75$ to $99 \%$ were considered as different cluster or an outlying branch. The branches of dendrogram signify that there is heterogeneity among the isolates

Cluster I included the highest number of isolates. This was split into two, split 1(a) includes four isolates and split 1(b) includes six isolates. The sequencing results revealed the identity of isolates belonging to cluster 1(a) and 1(b) as $P$. aeruginosa. Cluster II, the second largest cluster includes seven isolates. This cluster is split into two groups. 2(a) includes a single isolate, identified as Pseudomonas. sp., while 2(b) includes six isolates. All the isolates in cluster 2(b) are $100 \%$ similar. Clusters I and II share $50 \%$ similarity among them. Cluster III is split into 3(a) and 3(b). Isolates belonging to cluster 3(b) represent $100 \%$ similarity among them. Cluster 3(a) represented by one isolate is $60 \%$ similar to the split 3(b). Cluster III represents $55 \%$ similarity to the outlying branch (OB1) with a single isolate. The second outlying branch (OB2) includes two isolates 20 and 30 representing $100 \%$ similarity among them. Cluster IV includes two isolates representing $50 \%$ similarity among them. Cluster V is split into 5(a) that includes two isolates 39 and 42 having $100 \%$ 
Table 1 Tukey's post hoc test multiple comparisons for soil bacterial count

\begin{tabular}{|c|c|c|c|c|c|c|}
\hline \multicolumn{7}{|l|}{ Multiple comparisons } \\
\hline \multicolumn{7}{|c|}{ Dependent variable: soil bacterial count Tukey HSD } \\
\hline \multirow[t]{2}{*}{ (I) Soil } & \multirow[t]{2}{*}{ (J) Soil } & \multirow[t]{2}{*}{ Mean Difference $(\mathrm{I}-\mathrm{J})$} & \multirow[t]{2}{*}{ Std. error } & \multirow[t]{2}{*}{ Sig. ( $P$ value $)$} & \multicolumn{2}{|c|}{$95 \%$ confidence interval } \\
\hline & & & & & Lower bound & Upper bound \\
\hline \multirow[t]{5}{*}{ Pine surface soil (PSS) } & Pine deep & $7.00000 *$ & 1.79505 & $0.020^{\mathrm{a}}$ & 0.9706 & 13.0294 \\
\hline & Oak surface & $-19.00000^{*}$ & 1.79505 & $0.000^{\mathrm{c}}$ & -25.0294 & -12.9706 \\
\hline & Oak deep & $-8.00000^{*}$ & 1.79505 & $0.008^{\mathrm{b}}$ & -14.0294 & -1.9706 \\
\hline & Agriculture surface & 3.00000 & 1.79505 & $0.573^{\text {ns }}$ & -3.0294 & 9.0294 \\
\hline & Agriculture deep & $19.00000^{*}$ & 1.79505 & $0.000^{\mathrm{c}}$ & 12.9706 & 25.0294 \\
\hline \multirow[t]{5}{*}{ Pine deep soil (PDS) } & Pine surface & $-7.00000^{*}$ & 1.79505 & $0.020^{\mathrm{a}}$ & -13.0294 & -0.9706 \\
\hline & Oak surface & $-15.00000 *$ & 1.79505 & $0.000^{\mathrm{c}}$ & -21.0294 & -8.9706 \\
\hline & Oak deep & $-26.00000^{*}$ & 1.79505 & $0.000^{\mathrm{c}}$ & -32.0294 & -19.9706 \\
\hline & Agriculture surface & -4.00000 & 1.79505 & $0.293^{\text {ns }}$ & -10.0294 & 2.0294 \\
\hline & Agriculture deep & $12.00000 *$ & 1.79505 & $0.000^{\mathrm{c}}$ & 5.9706 & 18.0294 \\
\hline \multirow[t]{5}{*}{ Oak surface soil (OSS) } & Pine surface & $8.00000 *$ & 1.79505 & $0.008^{\mathrm{b}}$ & 1.9706 & 14.0294 \\
\hline & Pine deep & $15.00000 *$ & 1.79505 & $0.000^{\mathrm{c}}$ & 8.9706 & 21.0294 \\
\hline & Oak deep & $-11.00000^{*}$ & 1.79505 & $0.001^{\mathrm{b}}$ & -17.0294 & -4.9706 \\
\hline & Agriculture surface & $11.00000^{*}$ & 1.79505 & $0.001^{\mathrm{b}}$ & 4.9706 & 17.0294 \\
\hline & Agriculture deep & $27.00000 *$ & 1.79505 & $0.000^{\mathrm{c}}$ & 20.9706 & 33.0294 \\
\hline \multirow[t]{5}{*}{ Oak deep soil (ODS) } & Pine surface & $19.00000^{*}$ & 1.79505 & $0.000^{\mathrm{c}}$ & 12.9706 & 32.0294 \\
\hline & Pine deep & $26.00000 *$ & 1.79505 & $0.000^{\mathrm{c}}$ & 19.9706 & 17.0294 \\
\hline & Oak surface & $11.00000^{*}$ & 1.79505 & $0.001^{\mathrm{b}}$ & 4.9706 & 28.0294 \\
\hline & Agriculture surface & $22.00000 *$ & 1.79505 & $0.000^{\mathrm{c}}$ & 15.9706 & 44.0294 \\
\hline & Agriculture deep & $38.00000 *$ & 1.79505 & $0.000^{\mathrm{c}}$ & 31.9706 & 25.0294 \\
\hline \multirow[t]{5}{*}{ Agriculture surface soil (ASS) } & Pine surface & -3.00000 & 1.79505 & $0.573^{\text {ns }}$ & -9.0294 & 3.0294 \\
\hline & Pine deep & 4.00000 & 1.79505 & $0.293^{\text {ns }}$ & -2.0294 & 10.0294 \\
\hline & Oak surface & $-11.00000^{*}$ & 1.79505 & $0.001^{\mathrm{b}}$ & -17.0294 & -4.9706 \\
\hline & Oak deep & $-22.00000^{*}$ & 1.79505 & $0.000^{\mathrm{c}}$ & -28.0294 & -15.9706 \\
\hline & Agriculture deep & $16.00000^{*}$ & 1.79505 & $0.000^{\mathrm{c}}$ & 9.9706 & 22.0294 \\
\hline \multirow[t]{5}{*}{ Agriculture deep soil (ADS) } & Pine surface & $-19.00000^{*}$ & 1.79505 & $0.000^{\mathrm{c}}$ & -25.0294 & -12.9706 \\
\hline & Pine deep & $-12.00000^{*}$ & 1.79505 & $0.000^{\mathrm{c}}$ & -18.0294 & -5.9706 \\
\hline & Oak surface & $-27.00000^{*}$ & 1.79505 & $0.000^{\mathrm{c}}$ & -33.0294 & -20.9706 \\
\hline & Oak deep & $-38.00000 *$ & 1.79505 & $0.000^{\mathrm{c}}$ & -44.0294 & -31.9706 \\
\hline & Agriculture surface & $-16.00000^{*}$ & 1.79505 & $0.000^{\mathrm{c}}$ & -22.0294 & -9.9706 \\
\hline
\end{tabular}

$n s$ not significant

*Significance difference

${ }^{a}$ Significance at $5 \%(P$ value $<0.05)$

b Significance at $1 \%(P$ value $<0.01)$

${ }^{c}$ Significance at $0.1 \%(P$ value $<0.001)$

similarity among them. Isolate 42 is identified as $P$. tolassi, isolate 39 representing $100 \%$ similarity with 42 may also be $P$. tolassi. 5(b) includes isolate 50 identified as $P$. $f l u$ orescens and shares $100 \%$ similarity with isolates 15,47 , 48, and 49. Isolates $15,47,48$, and 49 may also be $P$. fluorescens. Cluster VI is split into two 6 (a) and 6 (b), having $75 \%$ similarity among them. Cluster 6(a) includes a single isolate and cluster 6(b) includes four isolates having $100 \%$ similarity among them. Isolate 46 forms an outlying branch (OB 3). OB3 is less than $60 \%$ similar to
Cluster VI. Cluster VII is split into two as 7(a) and 7(b). 7 (a) includes a single isolate which is $70 \%$ similar with 7(b). Isolate 35 identified as $P$. putida is $100 \%$ similar with 37 and 38. Hence, it can be said that the isolates belonging to cluster 7(b) may be $P$. putida. Cluster VIII is split into 8(a) and 8(b) with $40 \%$ similarity among them. Isolate belonging to 8 (b) represent $100 \%$ similarity among them. Isolate 7 forms an outlying baranch (OB4). Isolates 45 and 51 having less than $15 \%$ similarity among them form two outlying branch OB5 and OB6. 
Table 2 Tukey's post hoc test multiple comparisons for siderophore producing Pseudomonas isolates

Multiple comparisons

Dependent variable: siderophore producing Pseudomonas count Tukey HSD

\begin{tabular}{|c|c|c|c|c|c|c|}
\hline \multirow[t]{2}{*}{ (I) Soil } & \multirow[t]{2}{*}{ (J) Soil } & \multirow[t]{2}{*}{ Mean Difference $(\mathrm{I}-\mathrm{J})$} & \multirow[t]{2}{*}{ Std. error } & \multirow[t]{2}{*}{ Sig. $(P$ value $)$} & \multicolumn{2}{|c|}{$95 \%$ confidence interval } \\
\hline & & & & & Lower bound & Upper bound \\
\hline \multirow[t]{5}{*}{ Pine surface soil (PSS) } & Pine deep soil & 7.00000 & 1.82574 & $0.022^{\mathrm{a}}$ & 0.8675 & 13.1325 \\
\hline & Oak surface soil & 3.00000 & 1.82574 & $0.009^{\mathrm{b}}$ & -3.1325 & 9.1325 \\
\hline & Oak deep soil & -8.00000 & 1.82574 & $0.589^{\text {ns }}$ & -14.1325 & -1.8675 \\
\hline & Agriculture surface soil & 0.00000 & 1.82574 & $1.00^{\mathrm{ns}}$ & -6.1325 & 6.1325 \\
\hline & Agriculture deep soil & 7.00000 & 1.82574 & $0.022^{\mathrm{a}}$ & 0.8675 & 13.1325 \\
\hline \multirow[t]{5}{*}{ Pine deep soil (PDS) } & Pine surface soil & -7.00000 & 1.82574 & $0.022^{\mathrm{a}}$ & -13.1325 & -0.8675 \\
\hline & Oak surface soil & -4.00000 & 1.82574 & $0.309^{\text {ns }}$ & -10.1325 & 2.1325 \\
\hline & Oak deep soil & -15.00000 & 1.82574 & $0.000^{\mathrm{c}}$ & -21.1325 & -8.8675 \\
\hline & Agriculture surface soil & -7.00000 & 1.82574 & $0.022^{\mathrm{a}}$ & -13.1325 & -0.8675 \\
\hline & Agriculture deep soil & 0.00000 & 1.82574 & $1.00^{\mathrm{ns}}$ & -6.1325 & 6.1325 \\
\hline \multirow[t]{5}{*}{ Oak surface soil (OSS) } & Pine surface soil & 8.00000 & 1.82574 & $0.009^{\mathrm{b}}$ & 1.8675 & 14.1325 \\
\hline & Pine deep soil & 15.00000 & 1.82574 & $0.000^{\mathrm{c}}$ & 8.8675 & 21.1325 \\
\hline & Oak deep soil & 11.00000 & 1.82574 & $0.001^{\mathrm{b}}$ & 4.8675 & 17.1325 \\
\hline & Agriculture surface soil & 8.00000 & 1.82574 & $0.009^{\mathrm{b}}$ & 1.8675 & 14.1325 \\
\hline & Agriculture deep soil & 15.00000 & 1.82574 & $0.000^{\mathrm{c}}$ & 8.8675 & 21.1325 \\
\hline \multirow[t]{5}{*}{ Oak deep soil (ODS) } & Pine surface soil & -3.00000 & 1.82574 & $0.589^{\text {ns }}$ & -9.1325 & 3.1325 \\
\hline & Pine deep soil & 4.00000 & 1.82574 & $0.309^{\text {ns }}$ & -2.1325 & 10.1325 \\
\hline & Oak surface soil & -11.00000 & 1.82574 & $0.001^{\mathrm{b}}$ & -17.1325 & -4.8675 \\
\hline & Agriculture surface soil & -3.00000 & 1.82574 & $0.589^{\mathrm{ns}}$ & -9.1325 & 3.1325 \\
\hline & Agriculture deep soil & 4.00000 & 1.82574 & $0.309^{\text {ns }}$ & -2.1325 & 10.1325 \\
\hline \multirow[t]{5}{*}{ Agriculture surface soil (ASS) } & Pine surface soil & 0.00000 & 1.82574 & $1.00^{\mathrm{ns}}$ & -6.1325 & 6.1325 \\
\hline & Pine deep soil & 7.00000 & 1.82574 & $0.022^{\mathrm{a}}$ & 0.8675 & 13.1325 \\
\hline & Oak surface soil & 3.00000 & 1.82574 & $0.589^{\mathrm{ns}}$ & -3.1325 & 9.1325 \\
\hline & Oak deep soil & -8.00000 & 1.82574 & $0.009^{\mathrm{b}}$ & -14.1325 & -1.8675 \\
\hline & Agriculture deep soil & 7.00000 & 1.82574 & $0.022^{\mathrm{a}}$ & 0.8675 & 13.1325 \\
\hline \multirow[t]{5}{*}{ Agriculture deep soil (ADS) } & Pine surface soil & -7.00000 & 1.82574 & $0.022^{\mathrm{a}}$ & -13.1325 & -0.8675 \\
\hline & Pine deep soil & 0.00000 & 1.82574 & $1.00^{\mathrm{ns}}$ & -6.1325 & 6.1325 \\
\hline & Oak surface soil & -4.00000 & 1.82574 & $0.309^{\text {ns }}$ & -10.1325 & 2.1325 \\
\hline & Oak deep soil & -15.00000 & 1.82574 & $0.000^{\mathrm{c}}$ & -21.1325 & -8.8675 \\
\hline & Agriculture surface soil & -7.00000 & 1.82574 & $0.022^{\mathrm{a}}$ & -13.1325 & -0.8675 \\
\hline
\end{tabular}

$n s$ not significant

a Significant at $5 \%(P$ value $<0.05)$

b Significant at $1 \%(P$ value $<0.01)$

c Significant at $0.1 \%(P$ value $<0.001)$

Since the digestion site for the enzymes AluI (AG $\downarrow C T$ ) and RsaI (GT $\downarrow$ AC) was different, different restriction patterns were observed. The isolates representing $100 \%$ similarity on dendrogram may be same or with a difference in their subspecies. The sequencing results support the study that the isolates belong to different subgroups of Pseudomonas (sensu stricto). The isolates were segregated into different groups as $P$. aeruginosa, $P$. spp, $P$. tolassi, $P$. fluorescens, $P$. putida, and $P$. korensis, representing the heterogeneity among the isolates. Isolates from lesser or undisturbed lands of oak and pine forests were placed in all the clusters as the isolates from agricultural land or a disturbed land. In some of the clusters, isolates from forest and agricultural land are $100 \%$ similar. All of the Pseudomonas isolates were further explored for their PGPR properties. 
Fig. 1 Phylogenetic relationship among Pseudomonas isolates from pine forest, oak forest, and agricultural land of Himalayan region

\section{Physicochemical properties}

All the 51 Pseudomonas strains were investigated for the plant growth promotory (PGP) traits that include production of siderophore, $\mathrm{P}$-solubilization, $\mathrm{HCN}$ production, and IAA production. Results indicate that all the 51 isolates were siderophore producers and IAA producers. It was found $68.62 \%$ isolates were phosphate solubilizers and $62.74 \%$ were $\mathrm{HCN}$ producers. It was observed that $50 \%$ (23 strains) of the isolates were positive for all the PGP traits. Out of these 23 isolates 12 belonged to oak forest, 6 to pine forest and 5 to the agricultural land. These 23 isolates belong to different phylogenetic groups formed according to the RFLP results. Pseudomonas strains are beneficial and possess PGP traits and hence are explored the most. Among the more important attributes are, the ability to colonize roots successfully (colonization potential), sustain competition through release of bioactive

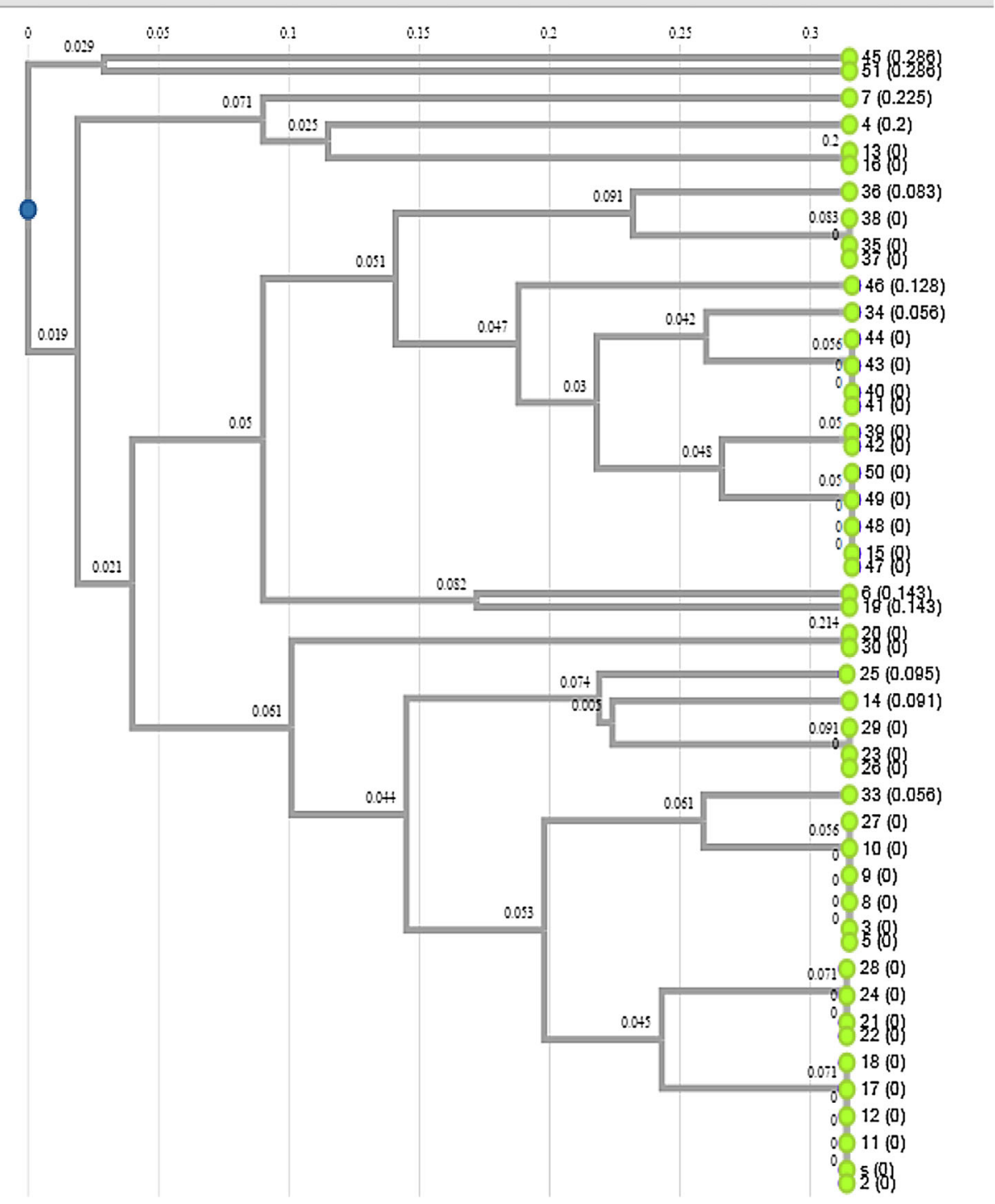

molecules, build up large populations during the growth stage of a plant in soil (Table 3 ).

\section{Discussion}

The diversity of plants and animals in forest and agroecosystem has been explored well, whereas the diversity of microorganism is often ignored. The greatest microbial diversity appears to reside in the soil (Zhou et al. 2003). Reduction in soil microbial diversity will result in the reduction of the functional capability of soil (Giller et al. 1997) as soil microorganisms play a very important role in soil fertility not only because of their ability to carry out biochemical transformation but also due to their importance as a source of mineral nutrients, cycling, and availability of nutrients required by the biological systems, the formation of soil organic matter, and decomposition of

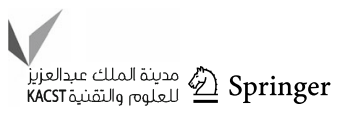


Table 3 Physicochemical properties of the Pseudomonas isolates

\begin{tabular}{|c|c|c|c|c|c|c|c|c|c|}
\hline Strain & $\begin{array}{l}\text { Siderophore } \\
\text { production }\end{array}$ & $\begin{array}{l}\text { Phosphate } \\
\text { solubilisation }\end{array}$ & $\begin{array}{l}\mathrm{HCN} \\
\text { production }\end{array}$ & $\begin{array}{l}\text { IAA } \\
\text { production }\end{array}$ & Strain & $\begin{array}{l}\text { Siderophore } \\
\text { production }\end{array}$ & $\begin{array}{l}\text { Phosphate } \\
\text { solubilisation }\end{array}$ & $\begin{array}{l}\mathrm{HCN} \\
\text { production }\end{array}$ & $\begin{array}{l}\text { IAA } \\
\text { production }\end{array}$ \\
\hline 1 & + & - & - & + & 27 & + & + & + & + \\
\hline 2 & + & + & + & + & 28 & + & + & - & + \\
\hline 3 & + & + & + & + & 29 & + & + & + & + \\
\hline 4 & + & - & + & + & 30 & + & + & + & + \\
\hline 5 & + & - & + & + & 31 & + & + & + & + \\
\hline 6 & + & + & + & + & 32 & + & - & - & + \\
\hline 7 & + & + & - & + & 33 & + & - & - & + \\
\hline 8 & + & + & + & + & 34 & + & + & + & + \\
\hline 9 & + & - & + & + & 35 & + & - & - & + \\
\hline 10 & + & - & - & + & 36 & + & + & + & + \\
\hline 11 & + & + & + & + & 37 & + & - & + & + \\
\hline 12 & + & + & + & + & 38 & + & + & - & + \\
\hline 13 & + & + & + & + & 39 & + & - & + & + \\
\hline 14 & + & + & + & + & 40 & + & + & + & + \\
\hline 15 & + & - & - & + & 41 & + & + & + & + \\
\hline 16 & + & - & - & + & 42 & + & + & - & + \\
\hline 17 & + & + & - & + & 43 & + & + & + & + \\
\hline 18 & + & + & - & + & 44 & + & + & - & + \\
\hline 19 & + & + & + & + & 45 & + & - & + & + \\
\hline 20 & + & + & + & + & 46 & + & + & - & + \\
\hline 21 & + & + & - & + & 47 & + & + & + & + \\
\hline 22 & + & + & + & + & 48 & + & + & + & + \\
\hline 23 & + & + & + & + & 49 & + & + & - & + \\
\hline 24 & + & + & + & + & 50 & + & + & - & + \\
\hline 25 & + & - & + & + & 51 & + & - & - & + \\
\hline 26 & + & + & + & + & & & & & \\
\hline
\end{tabular}

$H C N$ hydrogen cyanide, IAA indoleacetic acid production

+ Pseudomonas strains showing positive results for the respective test

- Pseudomonas strains showing negative results for the respective test

organic residues and detoxification of soil contaminants (Hendrix et al. 1990; Lavelle 1994) There have been studies on the distribution of microbial diversity in various environmental niches (Stolp 1988). Therefore, the diversity of microorganisms can be explored beneficially.

This study involves Pseudomonas from the forests (pine and oak) and agricultural lands of Indian Central Himalayan region. It was observed that higher number of Pseudomonas were isolated from pine surface, oak surface, and agricultural surface than the pine deep, oak deep, and agricultural deep soil. The alkalinity of oak soil (Upadhyay et al. 1989) supports the growth of Pseudomonas bacteria, while falling pine leaves and pesticide sprays make the pine soil and agricultural soil acidic, respectively, leading to decrease in the presence of Pseudomonas. Oak forests are also rich in the nutrients availability and fire free (Champion and Seth 1968) resulting in more microbial community biomass in oak soil.
Out of the 238 isolates, $21.4 \%$ of the total population was identified as siderophore producing Pseudomonas. These siderophores producing Pseudomonas isolates form eight different clusters that represent the different species or subspecies of Pseudomonas sensu stricto. Widmer et al. (1998) identified P. aeruginosa and other species, such as $P$. fluorescens, $P$. putida, and $P$. syringae, as members of a phylogenetically homogeneous group Pseudomonas (sensu stricto). All the 51 isolates were identified as Pseudomonas spp., P. aeruginosa, P. tolassi, P. fluorescens, $P$. putida, and $P$. korensis clustered in different groups. Some of the isolates share $100 \%$ identity among them, irrespective of their place of isolation. Isolates belonging to untouched lands of oak and pine forests were further explored for their physicochemical properties along with isolates from Agricultural land.

Growth promotion and disease control by Pseudomonas is complex interrelated processes involving direct and 
indirect mechanisms that include synthesis of some metabolites, production of siderophore, antibiotics, hydrogen cyanide (HCN), and volatile compounds. Others include mineral solubilization (e.g., phosphorus), competition, and induced systemic resistance (Adesemoye et al. 2008). Siderophore produced by fluorescent Pseudomonas rapidly colonizes the roots and significantly increases the plant growth by $144 \%$ in field tests (Kloepper et al. 1980; Sah and Singh 2015). In this study, 56 strains were siderophore producers, and these strains could be efficiently utilized for the plant growth promotion as siderophores mobilize insoluble iron from soil and increase biological availability for plants. Siderophores directly stimulate the biosynthesis of other antimicrobial compounds by increasing the availability of these minerals to bacteria (Sayyed et al. 2005). Phosphorus, an essential element for the plant health is made available to the plants by P-solubilizing microorganisms via production of organic acids. Phosphate-solubilizing fluorescent Pseudomonas brings about mobilization of insoluble phosphates in the soil and increase plant growth under conditions of poor phosphorus availability. In this study, we found that $68.62 \%$ of the isolates were able to solubilize phosphate indicating its utilization to provide soluble phosphate to the plant. In another study it was found that, $58.85 \%$ of the isolates were sharp P-solubilizers (Yadav et al. 2014). The secondary metabolite hydrogen cyanide (HCN) produced by fluorescent Pseudomonads is believed to be involved in the suppression of root pathogens. In this study, $62.74 \%$ isolates were found to produce HCN indicating its ability to inhibit root pathogens. Other researchers, e.g., Wani et al. (2007) and Ryall et al. (2009), also reported that HCN producing isolates help in the plant growth. The different Pseudomonas spp. (Pseudomonas entomophila) produce $\mathrm{HCN}$ and effectively suppress soil borne plant diseases. These strains could promote plant growth directly or indirectly or synergistically (Voisard et al. 1989). All of the 51 Pseudomonas isolates were able to produce IAA. IAA (indole-3-acetic acid) is the member of the group of phytohormones and is generally considered the most important native Auxin. IAA in different microorganism-plant interactions highlights the fact that bacteria use this phytohormone to interact with plants as part of their colonization strategy, including phytostimulation and circumvention of basal plant defense mechanisms (Voisard et al. 1989).

These tests reveal that $45.01 \%$ of the total isolates were able to show all the PGP traits checked. It was observed that isolates belonging to the undisturbed lands of oak forest were more efficient than isolates from pine forest and agricultural land. A higher number of isolates positive for all the properties (siderophore production, phosphate solubilization, HCN production, IAA production) were isolated from oak forest soil followed by pine forest and agriculture land (oak forest $>$ pine forest $>$ agricultural land). The PGPR properties of the isolates belonging to the unexplored forest soil can be beneficial for enhancing the plant productivity.

\section{Compliance with ethical standards}

Conflict of interest All authors have read and accepted the manuscript without any conflict of interest. The manuscript is not published elsewhere and is neither in processing.

Open Access This article is distributed under the terms of the Creative Commons Attribution 4.0 International License (http:// creativecommons.org/licenses/by/4.0/), which permits unrestricted use, distribution, and reproduction in any medium, provided you give appropriate credit to the original author(s) and the source, provide a link to the Creative Commons license, and indicate if changes were made.

\section{References}

Adesemoye AO, Obini MU, Goji EO (2008) Comparison of plant growth-promotion with Pseudomonas aeruginosa and Bacillus subtilis in three vegetables. Braz J Microbiol 39:423-426

Alström S, Burns RG (1989) Cyanide production by rhizobacteria as a possible mechanism of plant growth inhibition. Biol Fertil Soils 7(3):232-238

Bazzicalupo M, Fani R (1995) The use of RAPD for generating specific DNA probes for microorganisms. In: Clapp JP (ed) Methods in molecular biology. Humana, Totowa, pp 155-175q

Brick JM, Bostock RM, Silverstone SE (1991) Rapid in situ assay for indole acetic acid production by bacteria immobilized on nitrocellulose membrane. Appl Environ Microbiol 57:535-538

Champion HG, Seth SK (1968) A revised survey of forest types of India. Govt. of India Press, New Delhi, p 404

Giller KE, Cadish G, Ehaliotis C, Adams E, Sakala WD, Mafongoya PL (1997) Building soil nitrogen capital in Africa. In: Buresh, RJ, Sanchez PA and Calhoun FG (eds) Replenishing soil fertility in Africa. SSSA Special publication No 51, Madison, pp 151-192

Ginard M, Lalucat J, Tummler B, Romling U (1997) Genome organization of Pseudomonas stutzeri and resulting taxonomic and evolutionary considerations. Int J Syst Bacteriol 47:132-143

Gomila M, Pena A, Mulet M, Lalucat J, García-Valdés E (2015) Phylogenomics and systematics in Pseudomonas. Front Microbiol 6(214):1-12

Gould WD, Hagedorn C, Bardinelli TR, Zablotowicz RM (1985) New selective media for enumeration and recovery of fluorescent pseudomonads from various habitats. Appl Environ Microbiol 49:28-32

Hendrix PF, Crossley DA Jr, Blair JM, Coleman DC (1990) Soil biota as components of sustainable agroecosystems. In: Edwards CA, Lal R, Madden P, Miler RH, House G (eds) Sustainable agricultural systems. SWCS, Ankeny, pp 637-654

King EO, Ward MK, Raney DE (1954) Two simple media for the demonstration of payociamin and fluorescein. J Lab Clin Med 44:301-307

Kloepper JW, Schroth MN, Miller TD (1980) Effects of rhizosphere colonization by plant growth-promoting rhizobacteria on potato plant development and yield. Phytopathology 70:1078-1082

Lavelle P (1994) Faunal activities and soil processes: adaptive strategies that determine ecosystem function. Transactions of XVth Congress of ISSS, Ac Mexico, pp 189-220

Migula N (1894) Arbeiten aus dem Bakteriologischen Institutde Technischen Hochschule zu Karlsruhe 1:235-238

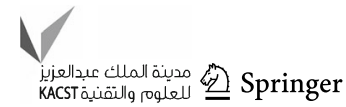


Moore ERB, Mua M, Arnscheidt A, Bottger EC, Hutso RA, Collins MD (1996) The determination and comparison of the 16SrDNA gene sequences of species of the genus Pseudomonas (sensu stricto) and estimation of the natural intrageneric relationships. Syst Appl Microbiol 19:476-492

Palleroni NJ (1984) Genus I. Pseudomonas Migula 1894. In: Kriegand NR, Holt JG (eds) Bergey's manual of systematic bacteriology, vol 1. Williams \& Wilkins, Baltimore, pp 141-199

Palleroni NJ (2008) The road to the taxonomy of Pseudomonas. In: Cornelis P (ed) Pseudomonas: genomics and molecular biology. Caister Acad Press, Hethersett, pp 1-18

Parte A (2014) LPSN-list of prokaryotic names with standing in nomenclature. Nucl Acids Res 42:D613-D616

Pikovskaya RI (1948) Mobilization of phosphorus in soil in connection with vital activity of some microbial species. Mikrobiologya 17:362-370

Rainey FA, Donnison AM, Janssen PH, Saul D, Rodrigo A, Bergquist PL, Daniel RM, Stackebrandt E, Morgan HW (1994) Description of Caldicellulosiruptor saccharolyticus gen. nov., sp. nov: an obligately anaerobic, extremely thermophilic, cellulolytic bacterium. FEMS Microbiol Lett 120(3):263-266

Ryall B, Mitchell H, Mossialos D, Williams HD (2009) Cyanogenesis by the entomopathogenic bacterium Pseudomonas entomophila. Lett Appl Microbiol 49(1):131-135

Sah S, Singh R (2015) Siderophore: structural and functional characterisation-a comprehensive review. Agric (Pol'nohospodárstvo) 61(3):97-114

Sah S, Sahgal M, Singh R (2016) Effect of Pseudomonas on micronutrient status of forest and agricultural soil of Uttarakhand. Ecol Environ Conserv. 22(April Suppl.):S279-S284

Sayyed R, Badgujar MD, Sonawane HM, Mhaske MM, Chincholkar SB (2005) Production of microbial iron chelators (siderophores) by fluorescent pseudomonads. Ind J Biotechnol 4:484-490

Schwyn B, Neilands JB (1987) Universal chemical assay for the detection and determination of siderophores. Anal Biochem 160:47-56
Spiers AJ, Buckling A, Rainey P (2000) The causes of Pseudomonas diversity. Microbiology 146:2345-2350

Stanier RY, Palleroni NJ, Doudoroff M (1966) The aerobic pseudomonads: a taxonomic study. J Gen Microbiol 43:159-271

Stolp H (1988) Microbial ecology: organisms, habitats, activities. Cambridge University Press, Cambridge

Torsvik TH, Smethurst MA, Meert JG, Van der Voo R, McKerrow WS, Sturt BA, Brasier MD, Walderhaug HJ (1996) Continental break-up and collision in the Neoproterozoic and Palaeozoic-a tale of Baltica and Laurentia. Earth Sci Rev 40:229-258

Upadhyay VP, Singh JS, Meyer MV (1989) Dynamics and weight loss of leaf litter in central Himalayan Forests: abiotic versus litter quality influences. J Ecol 77:147-161

Voisard C, Keel C, Haas D, Defago G (1989) Cyanide production by Pseudomonas fluorescens helps suppress black root rot of tobacco under gnotobiotic conditions. EMBO J 8:351-358

Wani PA, Khan MS, Zaidi A (2007) Co-inoculation of nitrogen-fixing and phosphate-solubilizing bacteria to promote growth, yield and nutrient uptake in chickpea. Acta Agron Hung 55(3):315-323

Widmer F, Seidler RJ, Gillevet PM, Watrud LS, Di Giovanni GD (1998) A highly selective PCR protocol for detecting 16S rRNA genes of the genus Pseudomonas (sensu stricto) in environmental samples. Appl Environ Microbiol 64:2545-2553

Winslow CE, Broadhurst AJ, Buchanan RE, Krumwiede C Jr, Rogers LA, Smith GH (1917) The families and genera of the bacteria. Preliminary report of the committee of the Society of American Bacteriologists on characterization and classification of bacterial types. J Bacteriol 2:505-566

Yadav S, Kaushik R, Saxena AK, Arora DK (2014) Genetic and functional diversity of fluorescent Pseudomonas from rhizospheric soils of wheat crop. J Basic Microbiol 54(5):425-437

Zhou L, Lei XH, Bochner BR, Wanner BL (2003) Phenotype microarray analysis of Escherichia coli K-12 mutants with deletions of all two-component systems. J Bacteriol 185(16):4956-4972 